\title{
The O2O Model of the Design MOOC Course Design
}

\author{
Xi Zhou* and Man Li \\ Chongqing University of Posts and Telecommunications, Chongqing, China \\ *Corresponding author: Xi Zhou, PhD, 342862686@qq.com
}

\begin{abstract}
The rapid expansion of the Internet has promoted the fission of the education method and the teaching model, the MOOC has become the representative education concepts and teaching methods of the Internet age, which is widely used in multidisciplinary teaching. The $\mathrm{O} 2 \mathrm{O}$ model of the design MOOC course design will laterally answer that how does the "Internet plus" era introduces MOOC to the design education and roots in it, and effectively transformed the Internet into an advantageous design teaching resource.
\end{abstract}

Key words: design MOOC; course design; the O2O model; flipped class; education reform

\section{Introduction}

It's now the holographic era, and the Internet is integrated into every field of society, education is no exception, the education industry has achieved its own revolution in the rapid development of the Internet, the rise and development of the MOOC promoted the fission of the education method and the teaching mode, the MOOC is widely used in all kinds of schools' teaching as the representative education concepts and teaching methods of the Internet age, and the proportion of the MOOC courses in university education is increasing. Design education in China starts late and its concept often lags behind the other subjects. How can the design education break through the traditional education idea and teaching method? Maybe China's "Internet plus" policy leads the design education to bring the opportunity of the curriculum reform and the teaching method's innovation, it is right time to introduce MOOC into education. Discipline education in design has its commonality with other disciplines, but also has its own personality, how can we blend and roots MOOC in the design education, which is worth exploring. The following will be discussed in the course design of the design MOOC O2O model.

MOOC is a unique type of Massive Open Online Course. This term appeared in 2008 and is rapidly growing around the world. MOOC includes massive, open and online three features. "Massive" is embodied in the huge number of people studying in the MOOC platform and ten thousands of registered students in one class; "online" means that all teaching and learning activities are conducted in the network, free of time and space constraints; “open” is embodied in the free MOOC learning, no matter anyone, as long as you are interested, can be free to sign up to study on the platform, even the world famous university classroom is within 
reach.

The year 2012 was called "the MOOC world". With the global rise of MOOC, the whole world has developed its own MOOC, the three most famous platforms are edx, Udacity and Coursera in the United States. The course pattern is roughly the same, the construction of the course comes from a group of congenial individuals, mainly taking "teaching and practicing" teaching methods, especially focusing on the learning of unicom and cooperation. Taking Coursera for example, each class will last 4-14 weeks depending on the difficulty of the course. After registration, the learners will autonomously arrange the time to watch the course video, which will be interspersed with small tests and after-class assignments. When it comes to the instant quizzes in video, video will automatically pause and leave the learners with sufficient time. The learners can also interact and discuss with each other through BBS or other ways. Differently from other MOOC platform only award a degree certificate to class-ending students, Coursera learners are required to comply with the integrity code in North America campus and complete the exam independently. In 2013, 5 courses' credits in Coursera have been officially recognized by America Education Commission, once the students complete these 5 courses, it is possible to convert the corresponding credit in college. In the past two years, MOOC have been rapidly developed at home, and many universities have joined in the exploration and construction of the "MOOC", the college of media arts of Chongqing University of Posts and Telecommunications where I located has started to combine the era of "Internet plus" to study the construction of the design MOOC. The primary starting point of this education reform is based on the old problem of teaching method which the higher education generally existed, especially in "Internet plus"era, the design major still follow the teaching method of industry period, most students' gaining way of knowledge is cramming, mainly relying on the classroom teacher, without other channel to obtain more knowledge and information from different perspectives; the second is design education, which has been trying so hard to cultivate interdisciplinary creative talents but with little success. In response to the times, the MOOC has opened up a new situation and opportunity for the cultivation and innovation of design education talents and also makes it possible to study independently. In this taken, replying on the Internet, it's the right time to carry out the reform of the design major courses with the new teaching mode, MOOC. However, according to its own characteristics and development experience, there are three problems that should be confronted and solved first during the MOOC construction: first, how to monitor the teaching activities; second, how to guarantee the completion rate and quality of the course; third, how to establish a rational learning evaluation mechanism. For the current students in China, it's hard to guarantee that they will complete the course entirely by self-management, even students who are intellectually driven; otherwise, the phenomenon of cheating in China's colleges is also objectively exist. Therefore, the first task is to study a feasible pattern of the design MOOC course design. According to the analysis of the above questions and discussions: the innovate idea to bring MOOC to the university needs to combine it with the 
traditional classroom and form a complementation. In other words, integrating online learning and face-to-face interaction is the core to ensure the effect and value of learning. According to this idea, the $\mathrm{O} 2 \mathrm{O}$ course design pattern of design MOOC is proposed.

$\mathrm{O} 2 \mathrm{O}$, Online To Offline. Online, students arrange the time to study on the campus MOOC platform, the course a knowledge module built by a teachers' team, and the students complete the course's online learning in the form of micro-video and small test; offline, teachers and students back to the classroom or the studio, as a coordinator and guidance, the teacher combines with the project teaching of the studio system, the another measure of the talent development innovation in media and art college, aiming at the discussion of the specific project and practicing the learning progress to improve the students' ability to solve problems, team work and explore their findings by applying knowledge. This course design pattern also reflects the idea of the flipped classroom, and also the transformation of learning styles of learning from one direction to co-innovation. Also, built a specific MOOC according to the O2O model, the online and offline courses' content needs to be designed independently, such as learning resources, teaching activities, learning evaluation, etc., but these two parts must be based on the same objective in the course design.

There are three core contents of course design will be specifically elaborated below: teaching resources, teaching activities and learning evaluation. Online teaching resources is centered on video, but MOOC is different from traditional online courses video, the teacher needs to break the whole course' knowledge into many small knowledge modules, each video contains a knowledge module, which takes about 10-20 minutes of study time. In this way, it takes less time to learn a module and makes it easier for students to schedule the time, meanwhile, with less information, the knowledge module is easier for students to learn, understand and accept, and attention is not easy to distract, guaranteeing the completion and quality of learning to some extent. In addition, the video page is best accompanied by the content of the main teacher's image and PowerPoint presentation, giving the students the feeling of being in the classroom. As a practical discipline, the design discipline especially emphasized the connection with the society, but the traditional teaching model rarely have such opportunities, thus, offline teaching resource should make a good use of the bridge between class and society that built by the MOOC, sharing resource and bringing design project to the class, letting students translated the knowledge studied online into design practice and also accumulating practical experience for the future.

The online teaching activities are mainly embodied in the interaction between students, "As three men are walking together, one of them is bound to be good enough to act as my teacher", students no longer entirely depend on their teacher for guidance, they can post their learning questions on the exclusive BBS of each course and answer others question, such interaction also helps strengthen students' learning motivation and promoting mutual learning among students. Of course, teachers can record and analyze the usage of various resources by using the large data, mastering each student's learning situation in real time and providing timely 
guidance when necessary. Offline teaching activity return to the interaction between teachers and students, the teacher needs to solve the online controversial problems of the students, and spread an online discussion of course assignments. In this way, the students experience the process of independent thinking -- communication between the students-- teachers' answer, and it's also strengthen the understanding and reinforcement of knowledge. On the basis of fully understanding of curriculum knowledge, the teachers' guide students to complete the specified design project, at the same time, the enterprise's design and research staff can also participate in classroom instruction and communication.

\section{Conclusions}

Online learning evaluation information derives from: testing, homework, and evaluation. Usually one course video contains one course test and feedback students timely. After all the video of one course complete learning, there will be a comprehensive course assignment adopted mutual mechanism with the student, then the teacher will offline organizes the student to discuss homework and answers questions. Teachers are the Offline learning evaluators, they should synthesize students' design project participation, learning attitude, team work and so on to give a comprehensive evaluation, finally, calculating the students' final evaluation according to the online and offline evaluations by a certain percentage.

The model is still in the process of further research, and it's both the opportunity and the challenge. For the current students which are born in the digital age, MOOC will undoubtedly inspire strong study interest, which is beneficial for the improvement of teaching quality; however, this is a difficult shift for most of teachers. MOOC can liberate teachers from repeating lectures, but also brings more responsibility and stress to teachers at the same time, and other series of issues, such as teaching management, credit recognition and technical support, are still exist. But all the process of reform and innovation will inevitably accompanied by the pain, in order to the cultivation of complex innovative design talents, to keep the design education forever active, the education workers must meet the coming challenges.

\section{References}

1. B. Yin, Y. Li, The development of MOOC and its implication for open universities, J. Journal of Beijing Open University, 2013,5.

2. Y. Ren, The cultivation and reform of college talents in the "MOOC", J. China Higher Education, 2014,7.

3. H. Deng, M. Li, Y. Chi, The construction of the course knowledge system in the “MOOC” era, J. Curriculum Education Research, 2013,7.

4. S. Haggard, The MOOC is maturing, J. Educational Research, 2014,5. 